\title{
Hepatotoxicity-Induced by the Therapeutic Dose of Acetaminophen and the Ameliorative Effect of Oral Co-administration of Selenium/ Tribulus terrestris Extract in Rats
}

\author{
Hepatotoxicidad Inducida por la Dosis Terapéutica de Acetaminofén y el Efecto de Mejora \\ de la Administración Conjunta de Extracto de Selenio Tribulus terrestris en Ratas
}

Amin A. Al-Doaiss ${ }^{1,2}$

AL-DOAISS, A. A. Hepatotoxicity-induced by the therapeutic dose of acetaminophen and the ameliorative effect of oral co-administration of selenium / Tribulus terrestris extract in rats. Int. J. Morphol., 38(5):1444-1454, 2020.

SUMMARY: Over dose or long-term clinical use of therapeutic doses of acetaminophen (APAP) causes hepatotoxicity. Various strategies attempted to ameliorate APAP-hepatotoxicity have been found to be unsuitable for clinical practice. This study was aimed to illustrate the histopathological changes induced by therapeutic dose of APAP and investigate the hepatoprotective role of oral coadministration of selenium/ Tribulus terrestris (TT) extract concurrently against hepatotoxicity induced by APAP in rats. Fifty-four healthy male albino Wistar rats were randomized into nine groups (G1-G9) of six rats each, and administered with APAP and TT orally for 30 days as follows: Control (2ml normal saline), APAP $(470 \mathrm{mg} / \mathrm{kg})$, APAP $(470 \mathrm{mg} / \mathrm{kg})+\operatorname{selenium~}(2 \mathrm{mg} / \mathrm{kg}), \mathrm{APAP}(470 \mathrm{mg} / \mathrm{kg})+$ TT (98 mg/kg), APAP (470 mg/kg) + selenium (2mg/kg) + TT (98 mg/kg), APAP (470 mg/kg) + silymarin (200 mg/kg), selenium (2 mg/ $\mathrm{kg})$, TT $(98 \mathrm{mg} / \mathrm{kg}$ ) and silymarin $(200 \mathrm{mg} / \mathrm{kg})$ groups. The results demonstrated that exposure of rats to therapeutic dose of APAP for 30 days caused significant histopathological changes parallel to elevated blood chemistry parameters. Co- administration of selenium/TT extract showed significantly reduced histopathological lesions and, restored or decreased levels of the examined blood chemistry parameters. Liver histology in selenium/TT extract showed normal hepatic architecture with mild changes and silymarin treated rats showed no histopathological changes. Histochemically PAS staining, showed that APAP-induced hepatotoxicity was characterized by hepatocytes glycogen depletion. Selenium/TT co-supplementation plays a potential role in preventing APAP-induced glycogen depletion by increasing detoxification and scavenging the reactive metabolites. Selenium/TT extract oral co-administration possesses a significant hepatoprotective property and mitigates APAP-induced hepatotoxicity by enhancing its antioxidant role and improving tissue integrity. Selenium/TT supplementation could represent an effective treatment against APAP-induced hepatotoxicity. Further studies are needed to elucidate the exact mechanism underlying the protective role of TT extract.

KEY WORDS: Acetaminophen; Selenium; Tribulus terrestris; Hepatotoxicity; Glycogen.

\section{INTRODUCTION}

Paracetamol or acetaminophen; (N-acety $1-\mathrm{p}-$ aminophenol; APAP), is an analgesic-antipyretic drug worldwide used as an over-the-counter drug and considered safe at therapeutic dose (AlWahsh et al., 2019). When administrated at therapeutic doses, APAP is safe with few side effects, but when used for a long time or over dosage, it can cause oxidative stress, hepatotoxicity, and liver/renal failure that can lead to death in both animals and human beings, with a mortality rate of up to $90 \%$. At overtherapeutic doses, APAP causes hepatotoxicity characterized by reactive metabolites, which are converted to normal metabolites by glutathione, and then excreted in the urine
(Ramachandran \& Jaeschke, 2017). At therapeutic doses for long periods or large doses, the levels of reactive metabolites increase and these metabolites react with proteins of the hepatocytes leading to glutathione depletion, oxidative stress, mitochondrial oxidative stress, and inhibition of ATP synthesis, eventually leading to cell necrosis, apoptosis, DNA fragmentation, and releasing the membrane proteins into the cytosol, which resulting in liver injury with cell damage and liver cell death (Ramachandran \& Jaeschke).

Most of the recent studies, which aimed to illustrate and identify the mechanism of APAP-induced hepatotoxicity

\footnotetext{
${ }^{1}$ Department of Biology, College of Science, King Khalid University, Abha, Saudi Arabia.

${ }^{2}$ Department of Anatomy and Histology, Faculty of Medicine, Sana'a University, Sana'a, Republic of Yemen.
} 
were performed on experimental animal models, histological alterations such as hepatic degeneration, necrosis, and oxidative stress in rodents, which lead to acute liver damage (Mahesh et al., 2009; Pettie et al., 2019). Several studies on experimental animals and humans have attempted to prevent or repair hepatotoxicity by APAP overdose (Iwalokun et al., 2006) or by recommended dosage (Kurtovic \& Riordan, 2003) through the pathways of glucuronidation and sulfation by cytochrome to form harmful reactive metabolites in order to prevent the toxicity or repair it (Hwang et al., 2008). Recently, utilization of natural products of medicinal plants has attracted research attention as a preferable strategy for the treatment of liver injury (Almasi et al., 2017).

Different agents and strategies associated with natural products that have antioxidant activity have been reported and successfully used to ameliorate or prevent APAP-hepatotoxicity, but they have not been found to be suitable for clinical practice (Verma et al., 2019; Zhou et al., 2019); theses natural products include Uraria picta (Kale et al., 2012), Kombucha tea (Abshenas et al., 2012), Curcuma longa (Khorsandi \& Orazizadeh, 2008), Plumbago zeylanica (Kanchana \& Sadiq, 2011), Wedelia calendulacea (Emmanuel et al., 2001), Ganoderma amboinense (Hsu et al., 2008), ajoene (Hattori et al., 2001), Vernonia amygdalina (Iwalokun et al.), Zingiber officinale (Yemitan \& Izegbu, 2006), Ginkgo biloba (Sener et al., 2006), red algae Porphyra yezoensis (Hwang et al.), Indian honey (Mahesh et al.), Mesna (Sener et al., 2005), Arabic gum (Gamal El-din et al., 2003). However, none of these strategies were found to be suitable or safe for clinical practice.

Tribulus terrestris (TT) (Zygophyllaceae family) is a dicotyledonous perennial creeping herb that is widely distributed and contain numerous bioactive compounds (Almasi et al.). T. terrestris is an annual herb widespread throughout Saudi Arabia and northern Yemen (Chaudhary \& Akram, 1987). Extracts of whole TT plant have been used since ancient times in traditional folk medicine as a tonic, diuretic, calculous affections aphrodisiac, analgesic, astringent, stomachic, antihypertensive, antimicrobial, antibacterial, antioxidant, treatment for painful urination, and antitoxic activities used in the treatment of diabetes, tumors, articular pains, respiratory diseases, cardiovascular diseases, reproductive dysfunctions, urinary anti-infective, and urinary stones; it also enhances testosterone levels in humans and mitigates oxidative damage, and thus, it is used by bodybuilders (Almasi et al.). TT contains steroids, saponins, flavonoids, alkaloids, unsaturated fatty acids, vitamins, tannins, resins, nitrate potassium, aspartic acid and glutamic acid (Almasi et al.).
Selenium (Se) is an essential trace element and micronutrient for livestock that is present in both organic and non-organic forms in the food (Qazi et al., 2019). It exerts known chemo-preventive and chemotherapeutic effects against various diseases caused by selenoproteins (Qazi et al.). Selenium is an antioxidant with complementary biological effects on thyroid function, reproduction (gonadal development, gametogenesis, and fertilization), and immunity, (protects the cells from destructive and harmful results of free radicals), which enhance human and animal health (Ghaffari et al., 2011). Selenium-deficiency is therefore linked with many disorders such as oxidative stress, myo-hepatic degeneration, and immunosuppression. The recommended daily allowance is $55 \mu \mathrm{g}$ in adults and $60 \mu \mathrm{g}$ in pregnant women. At high doses $\mathrm{Se}$ is toxic and can cause mortality (Mirone et al., 2013).

Silymarin has been widely used for decades in medical practice, particularly in the treatment of hepatotoxicity (Taju et al., 2011). "Milk thistle" is silymarin extract derived from the Silybum marianum plant. Silymarin is considered an anti-inflammatory, antioxidant, anticarcinogenic, and hepatoprotective medicinal plant (Taju et al.). It is marketed as one of the standard hepatoprotective herbal formulations (Kanchana \& Sadiq). In the current study similar to other studies, silymarin is usually used as a positive treatment against APAP-induced hepatotoxicity.

To date, most of the medical plants in Saudi Arabia have not been investigated to understand their biological and medical benefits (Al-Taweel et al., 2003; Kadriya et $a l .$, 2004). Therefore, in this study we hypothesized that oral co-administration of selenium/TT extract would be able to prevent APAP-induced deleterious effects in rat liver because of its intrinsic biochemical and free radicals scavenging properties.

\section{MATERIAL AND METHOD}

All the experiments were conducted in the Histology and Cell Biology Laboratory, Department of Biology, College of Science, King Khalid University, Saudi Arabia. All experimental protocols were approved by the Biomedical Research Ethical Committee at King Khalid University, Abha, Saudi Arabia.

Chemicals and drugs: Acetaminophen (APAP) in the form of paracetamol $(500 \mathrm{mg})$ was purchased from a local pharmacy. Selenium in the form [Sodium selenite $\left(\mathrm{Na}_{2} \mathrm{SeO}_{3}\right)$ ] was purchased from Oxoid Limited Co. UK. Silymarin was purchased from Sigma-Aldrich (St. Louis, MO, USA). 
Experimental animals: Adult male albino rats (150-200 g), were used for the current study. They were fed with standard commercial pallet diet and water ad libitum, and in polypropylene cages maintained under standard conditions (12-h light/dark cycle; $25 \pm 3^{\circ} \mathrm{C} ; 35-60 \%$ humidity), as well as under strict hygienic conditions. The animals were habituated to laboratory conditions for 7 days prior to the experiment to minimize any nonspecific stress.

Dosage, preparation and administration of test substances: The rat dose was calculated based on the surface area ratio. The maximum daily dose of APAP is $4000 \mathrm{mg}$ for an adult $(60 \mathrm{~kg})$ person. The dose for rat was calculated by dividing the maximum daily dose for adult person by adult human weight of $60 \mathrm{~kg}$ and multiplying it by the factor 7 to accommodate the body surface area of the animal; (4000 $\div 60)$ becomes $67 \mathrm{mg} / \mathrm{kg}$ b.w., the dose equivalent for rat $(67 \times 7)$ is $470 \mathrm{mg} / \mathrm{kg}$ b.w. (Freireich $e t$ al., 1966; Van Miert, 1986; Reagan-Shaw et al., 2008; Manimaran et al., 2010). The dose equivalent per $\mathrm{kg}$ for $\operatorname{rat}(\times 7)$ was derived by dividing the $\mathrm{km}$ factor (body surface area $\left(\mu^{2}\right)$ to body weight $(\mathrm{kg})$ ratio) for humans with the $\mathrm{Km}$ factor for rat species. The human dose of TT is 7000 $\mathrm{mg}$ for an adult $(60 \mathrm{~kg})$. Similarly, $(7000 \div 60)$ becomes 117 $\mathrm{mg} / \mathrm{kg}$ b.w., the dose equivalent for rat $(117 \times 7)$ is $820 \mathrm{mg} /$ $\mathrm{kg}$ b.w. The dose of the extract was determined with reference to the $\%$ yield of extract with the dose of crude drug and calculated as $98 \mathrm{mg} / \mathrm{kg}$ for TT (Saiyed et al., 2016).

APAP and Se were dissolved in distilled water, and the APAP-treated group received $470 \mathrm{mg} / \mathrm{kg} /$ day; APAP + selenium-treated group received APAP $(470 \mathrm{mg} / \mathrm{kg} /$ day $)+$ selenium $(2 \mathrm{mg} / \mathrm{kg} / \mathrm{day})$, APAP-TT extract-treated group received APAP $(470 \mathrm{mg} / \mathrm{kg} /$ day $)+$ TT extract $(98 \mathrm{mg} / \mathrm{kg} /$ day), silymarin-group received silymarin $(200 \mathrm{mg} / \mathrm{kg} /$ day $)$ and the control-group received $2 \mathrm{ml}$ of physiological saline alone. The preparations were administered by oral gavage in $5 \mathrm{ml} / \mathrm{kg}$ of body weight of each rat. TT plant was collected from the Southern area (Abha) of Saudi Arabia. The whole plant, excluding fruit was pulverized into powdery form using an industrial blender and the constituents were extracted with methanol using soxhlet apparatus (50 - 55 ${ }^{\circ} \mathrm{C}$ ) for three days. The extract was concentrated in a ventilated oven at $45^{\circ} \mathrm{C}$ for $24 \mathrm{~h}$. Dried powder of $45 \mathrm{~g}$ yielded an extract of about $10 \mathrm{~g}$, which was dark brown in color. The characteristics and bioactive constituents of TT were assessed previously by Reshma et al. (2019) in the plant list website (www.theplantlist.org).

Experimental design: A total of 54 healthy adult male albino rats (Rattus norvegicus) were randomly divided into nine groups ( $\mathrm{n}=6$ rats each) their dosing and route of administration provided in (Table I).

All the groups were treated for 30 consecutive days. At the end of this period, blood samples were collected from each rat, and their sera were separated and estimated for biochemical parameters. Later, the animals were sacrificed, and liver tissues were removed for histopathological examinations.

\section{Collection of serum and estimation of liver function:}

Blood samples were collected without any anticoagulant and allowed to clot for $10 \mathrm{~min}$ at room temperature. After coagulation, the blood was centrifuged at $0{ }^{\circ} \mathrm{C}$ to obtain the serum. The serum collected was stored at $-80^{\circ} \mathrm{C}$ until further use. Evaluation of enzymes for liver function including aspartate aminotransferase (AST), alanine aminotransferase (ALT), alkaline phosphatase (ALP), total bilirubin (TB), and total protein (TP) levels in serum were estimated by using standard enzymatic reagent strips (Reflotrone ${ }^{\circledR}$ plus system, Roche Diagnostic Ltd., Germany).

Histopathology: Small portions of the liver from each rat were removed, and fixed in formalin $(10 \%)$. The specimens were processed for dehydration using ascending grades of ethanol, clearing in xylene and impregnation with molten paraffin wax in an oven at $60^{\circ} \mathrm{C}$, using an automatic tissue processor (Sakura, Japan). Next, the tissues were embedded using an embedding station (Leica, Germany); sections (4$5 \mu \mathrm{m})$ were cut and stained with Hematoxylin and Eosin

Table I. Experimental study design.

\begin{tabular}{|c|c|c|}
\hline Group & Treatment & Dosage \\
\hline G1 & Control & Normal saline $2 \mathrm{ml} / \mathrm{kg} /$ day p.o \\
\hline G2 & APAP & $470 \mathrm{mg} / \mathrm{kg} /$ day p.o \\
\hline G3 & APAP+ Selenium & $\operatorname{APAP}(470 \mathrm{mg} / \mathrm{kg} /$ day p.o $)+$ selenium $(2 \mathrm{mg} / \mathrm{kg} /$ day $\mathrm{p} . \mathrm{o})$ \\
\hline G4 & $\mathrm{APAP}+\mathrm{TT}$ & $\operatorname{APAP}(470 \mathrm{mg} / \mathrm{kg} /$ day $\mathrm{p} . \mathrm{o})+\mathrm{TT}(98 \mathrm{mg} / \mathrm{kg} /$ day p.o $)$ \\
\hline G5 & APAP + Selenium $+\mathrm{TT}$ & $\operatorname{APAP}(470 \mathrm{mg} / \mathrm{kg} /$ day p.o $)+$ selenium $(2 \mathrm{mg} / \mathrm{kg} /$ day p.o $)+(98 \mathrm{mg} / \mathrm{kg} /$ day p.o $)$ \\
\hline G6 & APAP+ Silymarin & $\operatorname{APAP}(470 \mathrm{mg} / \mathrm{kg} /$ day p.o $)+$ Silymarin $(200 \mathrm{mg} / \mathrm{kg} /$ day p.o $)$ \\
\hline G7 & Selenium & $2 \mathrm{mg} / \mathrm{kg} /$ day p.o \\
\hline G8 & TT & $98 \mathrm{mg} / \mathrm{kg} /$ day p.o \\
\hline G9 & Silymarin & $200 \mathrm{mg} / \mathrm{kg} /$ day p.o \\
\hline
\end{tabular}


(H\&E) and PAS techniques as described previously (Al-Doaiss et al., 2019). The stained sections were examined using optical microscope (Olympus Microscope BP53 with Digital Camera, Japan). All subsequent histopathological examinations were performed by an experienced pathologist without knowledge of the previous treatments.

Statistical analysis: Results of biochemical parameters are presented as the mean \pm standard deviation (SD). Differences between means in all groups were tested for significance using the one-way analysis of variance (ANOVA) followed by Duncan's test and $\mathrm{P}<0.05$ was considered significant using the statistical analysis software SPSS (SPSS, 1996).

\section{RESULTS}

Biochemical parameters: The animals treated with APAP exhibited significant elevations in the liver profile parameters $(\mathrm{P}<0.05)$, i.e., ALP, AST, ALT, TB and TP serum levels, compared to those of the control, TT, Se, and silymarin groups (Table II).

\section{Histopathological studies}

Control Rats (G1): Microscopic examination of the control rats' liver demonstrated normal well-preserved architecture, intact normal histological components of the hepatic lobules, normal portal areas, and normal central vein bounded by an intact endothelium. Parallel hepatic strands radiate from the periphery of the liver lobules towards the central vein, and are Separated by narrow blood sinusoids in control livers (Fig. 1).
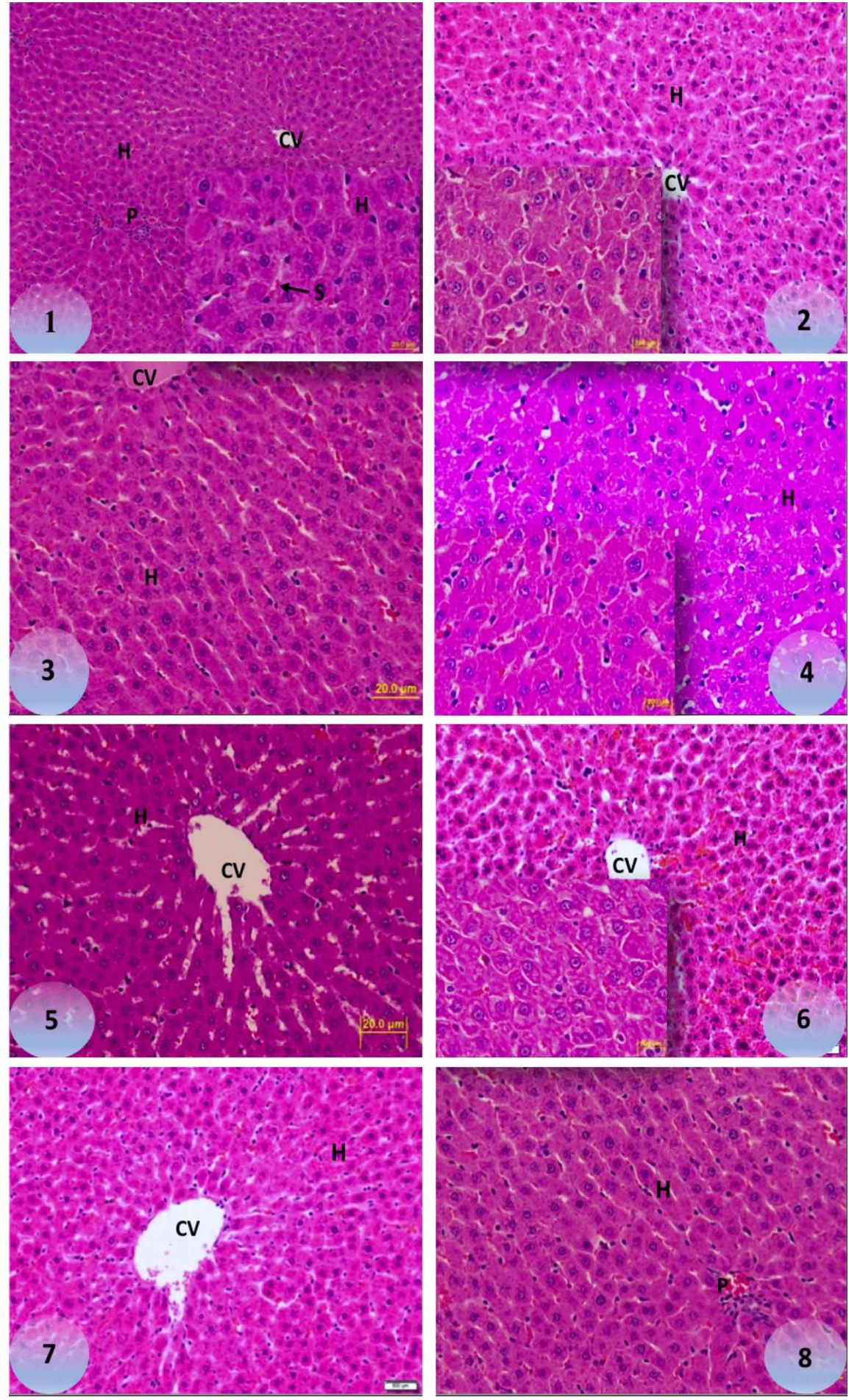

Figs. 1-8 Representative photomicrograph of a section of liver stained by (H\&E): Fig. 1. Control rat showing normal hepatic architecture with no histological changes, normal central vein $(\mathrm{CV})$. Parallel hepatic strands $(\mathrm{H})$ radiate from the periphery of the hepatic lobule toward the central vein and are separated by sinusoids $(\mathrm{S})$ and normal portal area (P). (H \& E; 100x). Inset (1000x); Figs. 2-8. 2. APAP+ selenium (200x), Inset (1000x); 3. selenium (400x.); 4. APAP+ TT (400x); 5. TT (400x); 6. APAP+ selenium + TT (200x.), Inset (1000x); 7. APAP + silymarin $(200 x)$ and 8 . silymarin-treated rats $(400 x)$, showing normal hepatic parenchyma with normal lobules, portal area $(\mathrm{P})$, hepatic cords $(\mathrm{H})$ and no lesion area. 
Table II. Biochemical parameters of liver: ALP, AST, ALT, Total bilirubin and Total protein serum levels in all groups.

\begin{tabular}{cllllll}
\hline Group & Treatment & ALP $(\mathrm{U} / \mathrm{L})$ & ALT $(\mathrm{U} / \mathrm{L})$ & AST $(\mathrm{U} / \mathrm{L})$ & T.B $(\mathrm{mg} / \mathrm{dl})$ & T.P $(\mathrm{g} / \mathrm{dl})$ \\
\hline G1 & Control & $75.14 \pm 2.3^{\mathrm{b}}$ & $48.34 \pm 3.4^{\mathrm{b}}$ & $85.23 \pm 6.4^{\mathrm{b}}$ & $1.57 \pm 0.21^{\mathrm{b}}$ & $6.50 \pm 0.34^{\mathrm{b}}$ \\
G2 & APAP & $123.25 \pm 5.2^{\mathrm{a}}$ & $117.15 \pm 5.6^{\mathrm{a}}$ & $144.17 \pm 2.9^{\mathrm{a}}$ & $4.44 \pm 0.15 \mathrm{a}$ & $3.43 \pm 0.12^{\mathrm{a}}$ \\
G3 & APAP+ selenium & $82.11 \pm 9.6^{\mathrm{b}}$ & $56.19 \pm 6.8^{\mathrm{b}}$ & $95.92 \pm 3.5^{\mathrm{b}}$ & $1.50 \pm 0.15^{\mathrm{b}}$ & $5.56 \pm 0.31^{\mathrm{b}}$ \\
G4 & APAP+ TT & $85.20 \pm 9.4^{\mathrm{b}}$ & $52.15 \pm 3.7^{\mathrm{b}}$ & $90.30 \pm 4.4^{\mathrm{b}}$ & $1.60 \pm 0.20^{\mathrm{b}}$ & $6.70 \pm 0.16^{\mathrm{b}}$ \\
G5 & APAP+ selenium+ TT & $81.25 \pm 2.6^{\mathrm{b}}$ & $50.10 \pm 7.1^{\mathrm{b}}$ & $88.41 \pm 2.2^{\mathrm{b}}$ & $1.64 \pm 0.11^{\mathrm{b}}$ & $6.33 \pm 0.43^{\mathrm{b}}$ \\
G6 & APAP+ silymarin & $77.21 \pm 6.4^{\mathrm{b}}$ & $53.72 \pm 4.5^{\mathrm{b}}$ & $92.46 \pm 1.2^{\mathrm{b}}$ & $1.57 \pm 0.10^{\mathrm{b}}$ & $5.37 \pm 0.22^{\mathrm{b}}$ \\
G7 & Selenium & $80.23 \pm 2.6^{\mathrm{b}}$ & $53.12 \pm 6.3^{\mathrm{b}}$ & $91.17 \pm 5.5^{\mathrm{b}}$ & $1.68 \pm 0.21^{\mathrm{b}}$ & $5.70 \pm 0.31^{\mathrm{b}}$ \\
G8 & TT & $89.16 \pm 8.9^{\mathrm{b}}$ & $51.14 \pm 2.3^{\mathrm{b}}$ & $92.24 \pm 2.3^{\mathrm{b}}$ & $1.70 \pm 0.13^{\mathrm{b}}$ & $6.25 \pm 0.15^{\mathrm{b}}$ \\
G9 & Silymarin & $76.27 \pm 5.5^{\mathrm{b}}$ & $49.28 \pm 5.8^{\mathrm{b}}$ & $87.15 \pm 4.9^{\mathrm{b}}$ & $1.55 \pm 0.27^{\mathrm{b}}$ & $6.88 \pm 0.27^{\mathrm{b}}$
\end{tabular}

The values are expressed as the means \pm standard error ( $\mathrm{n}=6$ animals per group)

The values having the same superscript within the column are not significantly ( $\mathrm{p}<0.05)$ different according to Duncan's multiple range test.

$\mathrm{AST}=$ Aspartate transaminase, $\mathrm{ALT}=$ Alanine transaminase, $\mathrm{ALP}=$ Alkaline phosphatase, $\mathrm{TB}=\mathrm{Total}$ bilirubin, $\mathrm{TP}=\mathrm{Total}$ protein

APAP + selenium-treated rats (G3) and seleniumtreated rats (G7). The liver section of APAP + selenium treated rats (G3) showed normal improvement in liver architecture and absence of histological alterations (Fig. 2), with mild cytoplasmic hydropic degeneration still visible. Additionally, (G7) selenium-treated group showed normal liver parenchyma (Fig. 3).

APAP + TT-treated rats (G4) and TT-treated rats (G8). The liver section of APAP $+98 \mathrm{mg} / \mathrm{kg}$ TT extract-treated rats (G4) showed improvement in liver architecture and absence of most of the histological alterations (Fig. 4), with mild cytoplasmic hydropic degeneration still visible. Additionally, $98 \mathrm{mg} / \mathrm{kg}$ TT extract-treated rats (G8) showed normal hepatic architecture (Fig. 5).

APAP + selenium + TT-treated rats (G5): The histological section of APAP + selenium + TT-treated rats (G5) showed normal hepatic lobule and improvement in liver architecture and absence of severe alterations with some mild cytoplasmic degeneration in the hepatocytes (Fig. 6).

Silymarin + APAP treated rats (G6) and silymarintreated rats (G9): The liver section of silymarin + APAPtreated-rats (G6) showed improvement in liver architecture (Fig. 7) Additionally, $200 \mathrm{mg} / \mathrm{kg}$ silymarin-treated rats (G9) showed normal hepatic architecture (Fig. 8).

APAP-treated rats (G2): The liver section in APAPtreated animals exhibited severe necrosis, intense congestion, steatohepatitis, karyopyknosis and nuclear changes (Fig. 6-20). The following histological alterations were identified in the liver of APAP-treated rats:

Necrosis: Marked parenchymal necrosis was noticed in the hepatocytes of APAP-treated rats in some areas of the liver (Fig. 9).
Steatosis (steatohepatitis): APAP-treated rats showed generalized steatosis (lipid droplet accumulation) in the viable hepatocytes (Fig. 10).

Blood (vessel and sinusoid) dilation: The blood sinusoids were dilated and congested, filled with RBCs and associated with karyopyknosis (Fig. 11). Additionally, the APAP-treated rats showed dilated congested central vein (Fig. 12).

Hydropic degenerations: Occasional hydropic degenerations associated with severe coagulative necrosis and cytoplasm swelling of the hepatocytes were detected in different areas of the liver of APAP-treated rats. (Fig. 13).

Disarray of hepatic cords, as well as disappearance of cell margins and hepatic architecture: The livers of APAP-treated rats lost their characteristic architecture; hepatocytes fused with each other, without any margins between the cells appeared, which might be due to the disappearance of their cell membranes (Fig. 14).

Karyorrhexis and karyolysis: Some hepatocytes showed nuclei disappearance and disruption in nuclear structure. Karyorrhexis is a fragmentation of the nuclei of the cells, initiated by karyopyknosis and followed by karyolysis (Figs. 15-16).

Hyaline material accumulation: Globular red hyaline materials were accumulated in hepatocytes as eosinophilic hyaline degenerative bodies or Mallory's hyaline bodies (Fig. 17).

Cholestasis: Cholestasis or bile accumulation in hepatocytes due to extrahepatic biliary tract obstruction was observed in APAP-treated animals (Fig. 18). 
Figs. 9-18. Representative photomicrographs of APAPtreated rat liver stained by (H\&E) showing: Fig. 9. necrosis (*) (400x); Fig. 10. dilation of congested blood sinusoids and steatosis $=$ steatohepatitis (arrows) (400x); Fig. 11. hemorrhages and karyopyknosis. (200x); Fig. 12. dilatation of congested central vein. (100x.); Fig. 13. hydropic degenerations (arrows) associated with severe coagulative necrosis (N) involving centrilobular region (zone (400x.); Fig. 14. disarray of hepatic cords (*) with pyknotic nuclei (400x); Fig. 15. steatohepatitis associated with karyorrehxis and karyolysis (400x); Fig. 16. high magnification image showing the microvesicular steatosis $(*)$ with karyopyknosis showing chromatin condensation (pykbosis), karyolysis and karyorrhexis of nuclei (arrow) (1000x); Fig. 17. eosinophilic hyaline degeneration or Mallory's hyaline (arrows). Globular red hyaline materials accumulate within the hepatocytes. (1000x). Fig. 18. cholestasis (arrows) associated with infiltration of inflammatory cells. Most often cholestasis is due to extrahepatic biliary tract obstruction. However, bile may also accumulate in liver (cholestasis) when there is hepatocyte injury (1000x).
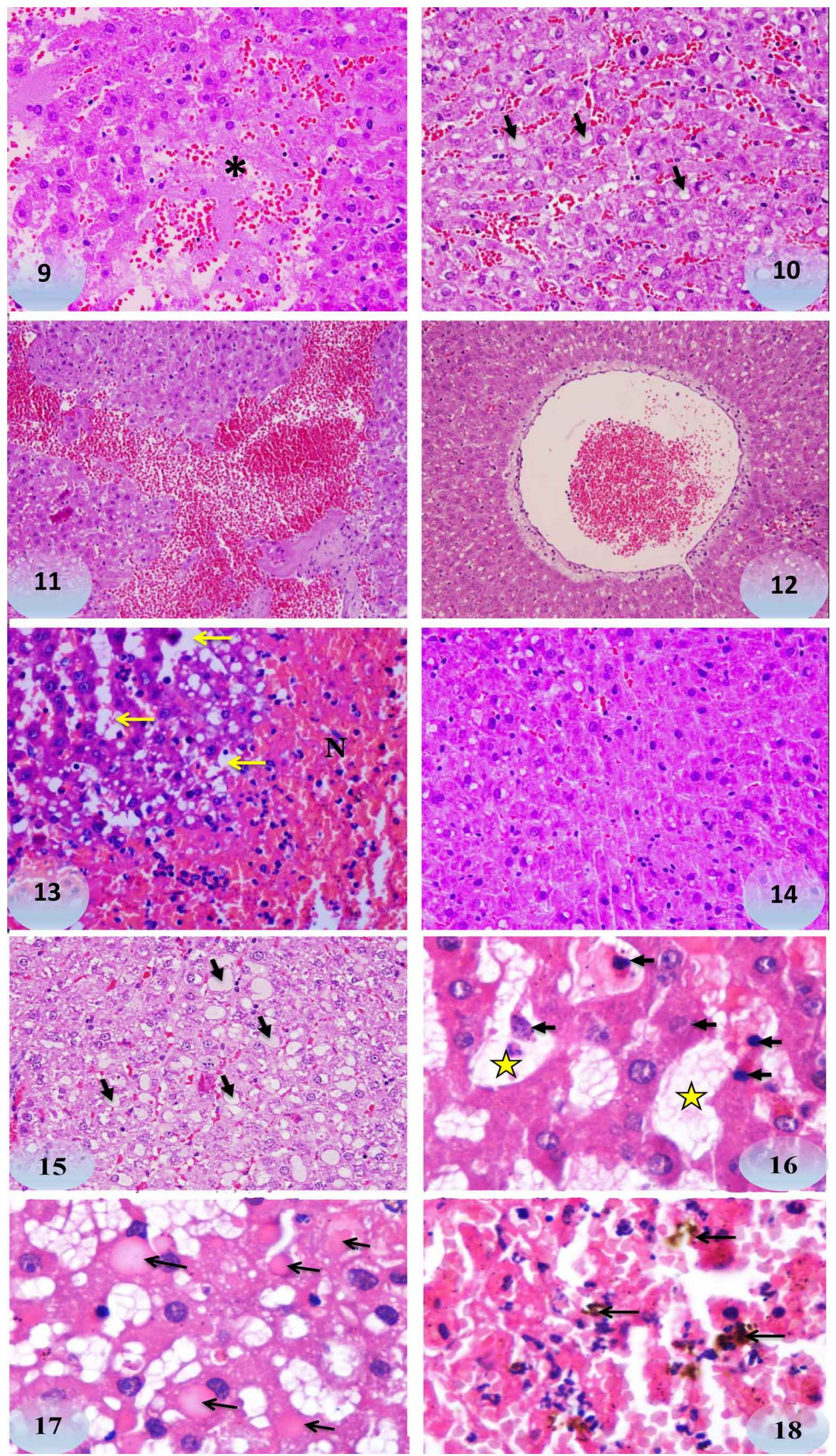

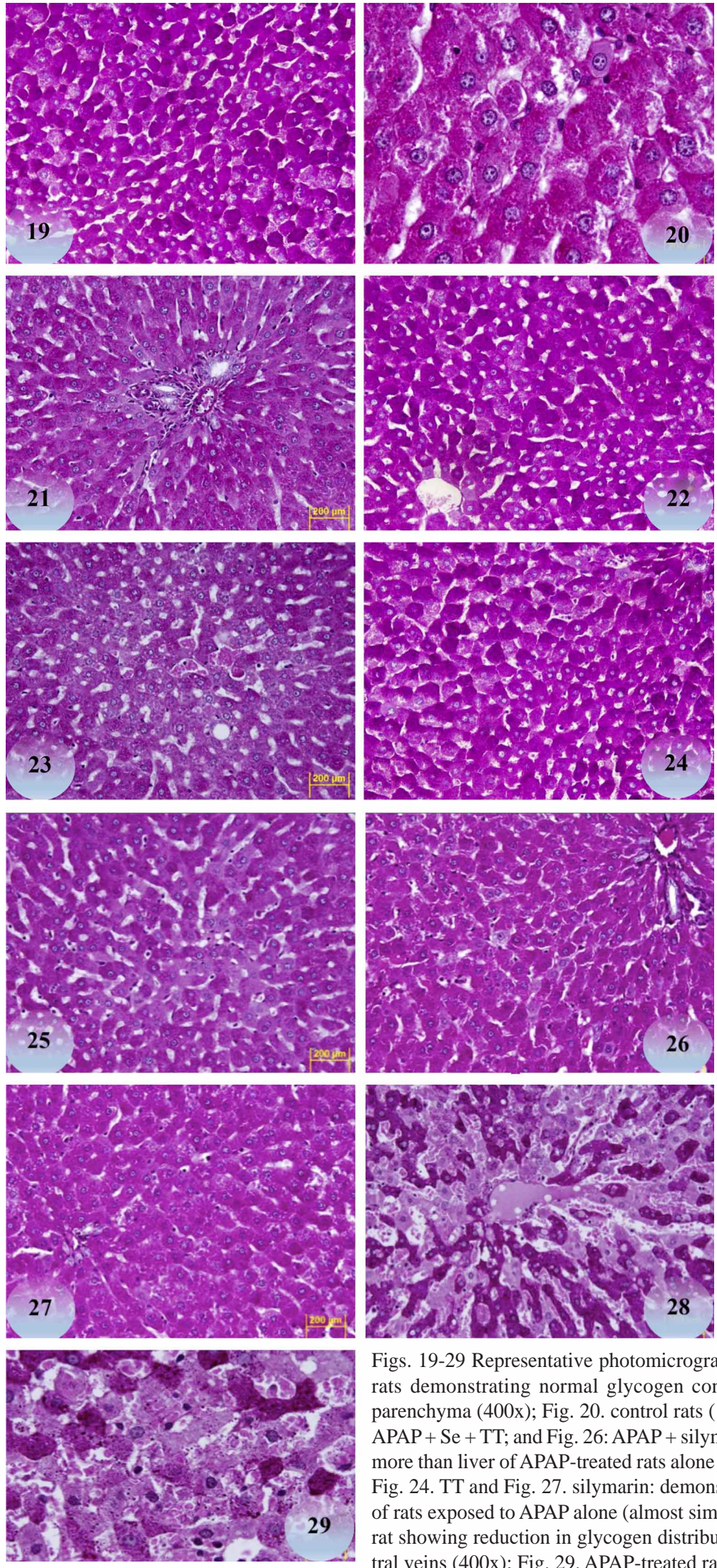

Figs. 19-29 Representative photomicrograph of a section of liver stained by (H\&E): Fig. 19: Control rats demonstrating normal glycogen content and distribution of magenta staining in the hepatic parenchyma (400x); Fig. 20. control rats (1000x); [Figs. 21. APAP + Se; Fig. 23. APAP + TT; Fig. 25. APAP + Se + TT; and Fig. 26: APAP + silymarin: demonstrating more improvement in glycogen content more than liver of APAP-treated rats alone but still less than that in the control rats (400x); Figs. 22. Se; Fig. 24. TT and Fig. 27. silymarin: demonstrating more glycogen content in comparison with the liver of rats exposed to APAP alone (almost similar to that of the control rats) (400x); Fig. 28. APAP-treated rat showing reduction in glycogen distribution, especially in perivascular hepatocytes around the central veins (400x); Fig. 29. APAP-treated rat (1000x). 
Table III. Semi-quantitative analysis of histopathological studies on rat liver in different groups.

\begin{tabular}{|c|c|c|c|c|c|c|c|c|c|}
\hline స్ & Treatment & Necrosis & $\begin{array}{l}\text { Infiltration of } \\
\text { inflammatory } \\
\text { cells }\end{array}$ & $\begin{array}{l}\text { Nuclear } \\
\text { changes }\end{array}$ & $\begin{array}{l}\text { Fatty } \\
\text { degeneration }\end{array}$ & $\begin{array}{l}\text { Congestion of } \\
\text { hepatic tissue }\end{array}$ & $\begin{array}{l}\text { Hydropic } \\
\text { degeneration }\end{array}$ & Cholestasis & $\begin{array}{l}\text { Glycogen } \\
\text { content } \\
\text { (magenta color) }\end{array}$ \\
\hline G1 & Control & - & - & - & _ & - & - & _ & +++ \\
\hline G2 & APAP & ++++ & ++++ & +++ & +++ & +++ & +++ & ++ & + \\
\hline G3 & $\mathrm{APAP}+$ selenium & - & + & - & - & + & + & - & ++ \\
\hline G4 & $\mathrm{APAP}+\mathrm{TT}$ & - & + & - & - & - & + & - & ++ \\
\hline G5 & $\mathrm{APAP}+$ selenium $+\mathrm{TT}$ & - & - & _ & - & + & + & - & ++ \\
\hline G6 & APAP+ silymarin & - & + & - & _- & + & _ & _ & ++ \\
\hline G7 & Selenium & _ & - & _ & _ & + & + & - & +++ \\
\hline G8 & $\mathrm{TT}$ & - & - & - & - & + & _- & - & +++ \\
\hline G9 & Silymarin & - & - & - & - & + & _ & - & +++ \\
\hline
\end{tabular}

APAP $=$ Acetaminophen, $\mathrm{TT}=$ Tribulus terrestris, $(-)$ indicates normal, $(+)$ indicates mild, $(++)$ indicates moderate, $(+++)$ indicates severe, and $(++++)$ indicates extremely severe.

during prolonged use, antitussive, antibacterial, antifungal, anti-inflammatory, and anti-oxidant effects (Wang et al.). Recently, many experimental studies have demonstrated the protective effects of several natural products against APAPinduced hepatotoxicity due to their actions as antiinflammatory and anti-oxidant agents, and damage reparative response (Lv et al., 2018).

The determination of the biomarkers (ALT, AST, and $\mathrm{AL}$ ), TB, and TP are linked to hepatocyte function and integrity and can be used for the evaluation of hepatic injury (Rashid $e t$ al., 2016). Serum enzyme levels have been described as potential indicators of necrosis and liver injury (Yoon et al., 2016). ALT is an effective biochemical marker for evaluating liver function. Serum AST, ALP, and bilirubin are also associated with liver injury and widely used as hepatic markers to evaluate hepatotoxicity or liver diseases (Girish et al., 2009). APAP-induced acute liver failure was characterized by histopathological changes parallel with elevation of blood chemistry parameters' levels. Increase in enzyme levels are attributed to cellular leakage due to loss of selective permeability of cell membranes of hepatocytes. Hepatic enzymes are located in the cytoplasm but leak into circulatory blood after hepatotoxicity (Wang et al.). Chronic administration of acetaminophen produced a marked elevation of enzymes levels in APAP-treated rat.

In contrast, the co-administration of selenium/TT extract prevented the elevation of hepatic biochemical enzymes levels, which were near the normal level, and repaired of APAP-damaged hepatic tissues. This corresponds with the commonly accepted view that serum levels of liver enzymes return to normal after the hepatic tissue heals. ALP level is related to the response to cholestasis and biliary pressure after APAP administration. Serum bilirubin evaluation is one of the most sensitive tests employed for the diagnosis of hepatic diseases. Hyperbilirubinemia has been previously observed due to excessive heme destruction and blockage of biliary tract (Wolf et al., 1997). Administration of selenium/ TT extract increased the level of protein, suggesting that it offered protection. The elevated levels of all liver enzymes and other parameters were decreased to near normal levels after 30-day treatment of selenium/ TT extract, indicating that it offered protection by preserving the structural integrity of the hepatocellular membrane against APAP and probably because of their membrane stabilizing activity which prevents leakage of intracellular enzymes.

In the current study, the histopathological investigations revealed the infiltration of inflammatory cells associated with necrosis in the livers of APAP-treated rats, and this finding concurs with that of Papackova et al. (2018). Hepatocytes of APAP-treated rats showed blood vessel \& sinusoid congestion, hydropic degeneration, microvesicular fatty change vacuolation, eosinophilia, and scattered foci of necrosis with nuclear changes (pyknosis, karyolysis and karyorrhexis).

In the present study, co-treatment with selenium/TT extract inhibited all alterations of APAP- induced toxicity. This protective role could be due to their ant oxidative activity mediated through free radical scavenging or production (Rashid et al.; Wang et al.). Moreover, enzyme levels in the serum and histopathological changes in the liver were mitigated and almost abolished in the APAP-treated group compared with the control group, after co-treatment with selenium/TT extract.

Histopathological assessments of tissues (tissue-based pathology) are important tools that are considered a cornerstone technique for evaluating the effects of medications or chemicals in biomedical studies, particularly those studying experimental animals related to human diseases. Histochemical staining is an essential method for tissue evaluation. There are several histological and histochemical staining techniques 
that are used for detection of the chemical components of tissues. For example, H\&E is a routine stain that is used for tissue examination in histology. Other special histochemical methods include periodic acid Schiff (PAS), which can bind to specific biochemical contents and serve as effective indicators used for the evaluation of histological alterations. PAS is evidently a specific stain used for detecting of glycogen in the liver and neutral mucins in other organs (Meyerholz et al., 2018). Administration of APAP at therapeutic dose for 30 days caused sever hepatocytes glycogen depletion in the liver of the treated rats. This histochemical change could be due to the direct effects of APAP on the enzymes involved in the processes of glycogenesis, glycolysis or glucose absorption. The liver cells in the perivascular zones were more affected. This change refers to glycolysis, which was more affected than glycogenesis after APAP administration. Glycogen depletion in APAP-treated rats was associated with the harmful role of reactive metabolites. These results correspond with the findings of a previous study on mice treated with APAP (500 mg/kg, i.p.) (Hinson et al., 1983). Selenium/TT extract treatment of rats prevents APAPinduced glycogen depletion by increasing detoxification through reactive metabolite scavenging (Hinson et al.). Glycogen is an immediate fuel source found in the cytoplasm of cardiac (2\%), skeletal muscle (1-2\%), and liver cells (5-6\%). The glycogen particles in hepatocytes can be 10 -fold larger than those in skeletal myocytes (Murray \& Rosenbloom, 2018).

\section{CONCLUSION}

Our results demonstrate that therapeutic dose of APAP for 30 days is capable of inducing marked hepatic histological and biochemical alterations in rats. Additionally, the present results provide strong evidence that the co-administration of selenium/TT extract inhibits and ameliorates hepatotoxic effects induced by APAP, and this role was possibly mediated through free radical scavenging or inhibition of free radical generation. Further studies are required, to assess hepatoprotective effects of medicinal plant extracts against APAP toxicity to confirm these protective effects.

\section{ACKNOWLEDGMENTS}

The author extends their appreciation to the Deanship of Scientific Research at King Khalid University, Abha, KSA for funding this work through Research Group Project under grant number (R.G.P1/158/40).
AL-DOAISS, A. A. Hepatotoxicidad inducida por la dosis terapéutica de acetaminofén y el efecto de mejora de la administración conjunta de extracto de selenio / Tribulus terrestris en ratas. Int. J. Morphol., 38(5):1444-1454, 2020.

RESUMEN: La dosis excesiva o el uso clínico a largo plazo de dosis terapéuticas de acetaminofeno (APAP) causa hepatotoxicidad. Se ha descubierto que varias estrategias que intentaron mejorar la hepatotoxicidad por APAP no son adecuadas para la práctica clínica. Este estudio tuvo como objetivo ilustrar los cambios histopatológicos inducidos por la dosis terapéutica de APAP e investigar el papel hepatoprotector de la administración conjunta de extracto de selenio / Tribulus terrestris (TT) simultáneamente contra la hepatotoxicidad inducida por APAP en ratas. Cincuenta y cuatro ratas Wistar albino machos sanas se aleatorizaron en nueve grupos (G1 - G9) de seis ratas cada una, y se administraron con APAP y TT por vía oral durante 30 días de la siguiente manera: Control ( $2 \mathrm{ml}$ de solución salina normal), APAP (470 mg / kg), APAP (470 mg / kg) + selenio (2 mg / kg), APAP $(470 \mathrm{mg} / \mathrm{kg})+\mathrm{TT}(98 \mathrm{mg} / \mathrm{kg}), \operatorname{APAP}(470 \mathrm{mg} / \mathrm{kg})+$ selenio $(2$ $\mathrm{mg} / \mathrm{kg})+\mathrm{TT}(98 \mathrm{mg} / \mathrm{kg})$, APAP $(470 \mathrm{mg} / \mathrm{kg})+$ silimarina $(200$ $\mathrm{mg} / \mathrm{kg}$ ), selenio (2 mg / kg), TT (98 mg / kg) y silimarina (200 mg / kg). Los resultados demostraron que la exposición de las ratas a la dosis terapéutica de APAP durante 30 días causó cambios histopatológicos significativos paralelos a parámetros elevados de química sanguínea. La administración conjunta de extracto de selenio / TT mostró lesiones histopatológicas significativamente reducidas y niveles restaurados o disminuidos de los parámetros de química sanguínea. La histología hepática en el extracto de selenio / TT mostró una arquitectura hepática normal con cambios leves y las ratas tratadas con silimarina no mostraron cambios histopatológicos. La tinción histoquímica de PAS mostró que la hepatotoxicidad inducida por APAP se caracterizó por la pérdida de glucógeno de los hepatocitos. La suplementación con selenio / TT juega un papel potencial en la prevención de la pérdida de glucógeno inducido por APAP al aumentar la desintoxicación y eliminar los metabolitos reactivos. La administración conjunta de extracto de selenio / TT posee una propiedad hepatoprotectora significativa y mitiga la hepatotoxicidad inducida por APAP al mejorar su papel antioxidante y la integridad del tejido. La suplementación con selenio / TT podría representar un tratamiento efectivo contra la hepatotoxicidad inducida por APAP. Se necesitan más estudios para dilucidar el mecanismo exacto que subyace a la función protectora del extracto TT.

PALABRAS CLAVE: Acetaminofeno; Selenio; Tribulus terrestris; Hepatotoxicidad;Glucógeno.

\section{REFERENCES}

Abshenas, J.; Derakhshanfar, A.; Ferdosi, M. H. \& Hasanzadeh, S. Protective effect of Kombucha tea against acetaminophen-induced hepatotoxicity in mice: a biochemical and histopathological study. Comp. Clin. Pathol., $21: 1243-8,2012$.

Adeneye, A. \& Olagunju, J. Protective effect of oral ascorbic acid (vitamin c) against acetaminophen- induced hepatic injury in rats. Afr. J. Biomed. Res., 11(2):183-90, 2008. 
Al-Doaiss, A. A.; Ali, D.; Ali, B. A. \& Jarrar, B. M. Renal histological alterations induced by acute exposure of titanium dioxide nanoparticles. Int. J. Morphol., 37(3):1049-57, 2019.

Al-Taweel, A. M.; El-Deeb, K. S. \& Al-Muhtadi, F. J. Chemical composition and antimicrobial activity of the essential oil of Kleinia odora. Saudi Pharma. J., 12(1):47-50, 2003.

Almasi, F.; Khazaei, M.; Chehrei, S. \& Ghanbari, A. Hepatoprotective effects of Tribulus terrestris hydro-alcholic extract on nonalcoholic fatty liver- induced rats. Int. J. Morphol., 35(1):345-50, 2017.

AlWahsh, M.; Othman, A.; Hamadneh, L.; Telfah, A.; Lambert, J.; Hikmat, S.; Alassi, A.; Mohamed, F. E. Z.; Hergenröder, R.; AlQirim, T.; et al. Second exposure to acetaminophen overdose is associated with liver fibrosis in mice. EXCLI J., 18:51-62, 2019.

Bhushan, B. \& Apte, U. Liver regeneration after acetaminophen hepatotoxicity: mechanisms and therapeutic opportunities. Am. J. Pathol., 189(4):719-29, 2019.

Chaudhary, S. A. \& Akram, M. Weeds of Saudi Arabia and the Arabian Peninsula. Riyadh, National Herbarium, Regional Agriculture and Water Research Center, Ministry of Agriculture and Water, 1987.

Emmanuel, S.; Amalraj, T. \& Ignacimuthu, S. Hepatoprotective effect of coumestans isolated from the leaves of Wedelia calendulacea Less. in paracetamol induced liver damage. Indian J. Exp. Biol., 39(12):1305-7, 2001.

Freireich, E. J.; Gehan, E. A.; Rall, D. P.; Schmidt, L. H. \& Skipper, H. E. Quantitative comparison of toxicity of anticancer agents in mouse, rat, hamster, dog, monkey, and man. Cancer Chemother. Rep., 50(4):219-44, 1966.

Gamal El-din, A. M.; Mostafa, A. M.; Al-Shabanah, O. A.; Al-Bekairi, A. M. \& Nagi, M. N. Protective effect of Arabic gum against acetaminophen-induced hepatotoxicity in mice. Pharmacol. Res., 48(6):631-5, 2003.

Ghaffari, T.; Nouri, M.; Irannejad, E. \& Rashidi, M. R. Effect of vitamin $\mathrm{E}$ and selenium supplement on paraoxonase-1 activity, oxidized low density lipoprotein and antioxidant defense in diabetic rats. Bioimpacts, 1(2):121-8, 2011.

Girish, C.; Koner, B. C.; Jayanthi, S.; Rao, K. R.; Rajesh, B. \& Pradhan, S. C. Hepatoprotective activity of six polyherbal formulations in paracetamol induced liver toxicity in mice. Indian J. Med. Res., 129(5):569-78, 2009.

Hattori, A.; Yamada, N.; Nishikawa, T.; Fukuda, H. \& Fujino, T. Protective effect of ajoene on acetaminophen-induced hepatic injury in mice. Biosci. Biotechnol. Biochem., 65(11):2555-7, 2001.

Hinson, J. A.; Mays, J. B. \& Cameron, A. M. Acetaminophen-induced hepatic glycogen depletion and hyperglycemia in mice. Biochem. Pharmacol., 32(13):1979-88, 1983.

Hsu, C. C.; Lin, K. Y.; Wang, Z. H.; Lin, W. L. \& Yin, M. C. Preventive effect of Ganoderma amboinense on acetaminophen-induced acute liver injury. Phytomedicine, 15(11):946-50, 2008.

Hwang, H. J.; Kwon, M. J.; Kim, I. H. \& Nam, T. J. Chemoprotective effects of a protein from the red Algae porphyra yezoensis on acetaminophen-induced liver injury in rats. Phytother. Res., 22(9):1149-53, 2008.

Iwalokun, B. A.; Efedede, B. U.; Alabi-Sofunde, J. A.; Oduala, T.; Magbagbeola, O. A. \& Akinwande, A. I. Hepatoprotective and antioxidant activities of Vernonia amygdalina on acetaminopheninduced hepatic damage in mice. J. Med. Food, 9(4):524-30, 2006.

Kadriya, E. D. S.; Abbas, F. A.; El Fishawy, A. \& Mossa, J. S. Chemical composition of the essential oil of Tagetes minuta growing in Saudi Arabia. Saudi Pharm. J., 12(1):51-53, 2004.

Kale, R. H.; Halde, U. K. \& Biyani, K. R. Protective Effect of aqueous extract of Uraria picta on acetaminophen induced nephrotoxicity in rats. Int. J. Res. Pharm. Biomed. Sci., 3(1):110-3, 2012.

Kanchana, N. \& Sadiq, A. M. Hepatoprotective effect of Plumbago zeylanica on paracetamol induced liver toxicity in rats. Int. J. Pharm. Pharm. Sci., 3(1):151-4, 2011.
Khorsandi, L. \& Orazizadeh, M. Protective effect of Curcuma longa extract on acetaminophen induced nephrotoxicity in mice. DARU J. Pharm. Sci., 16(3):155-9, 2008.

Kurtovic, J. \& Riordan, S. M. Paracetamol-induced hepatotoxicity at recommended dosage. J. Intern. Med., 253(2):240-3, 2003.

Lv, H.; Xiao, Q.; Zhou, J.; Feng, H.; Liu, G. \& Ci, X. Licochalcone A upregulates $\mathrm{Nrf} 2$ antioxidant pathway and thereby alleviates acetaminophen-induced hepatotoxicity. Front. Pharmacol., 9:147, 2018.

Mahesh, A.; Shaheetha, J.; Thangadurai, D. \& Rao, D. M. Protective effect of Indian honey on acetaminophen induced oxidative stress and liver toxicity in rat. Biologia, 64:1225, 2009.

Manimaran, A.; Sarkar, S. N. \& Sankar, P. Influence of repeated preexposure to arsenic on acetaminophen-induced oxidative stress in liver of male rats. Food Chem. Toxicol., 48(2):605-10, 2010.

Meyerholz, D. K. \& Beck, A. P. Principles and approaches for reproducible scoring of tissue stains in research. Lab. Invest., 98(7):84455, 2018.

Meyerholz, D. K.; Beck, A. P.; Goeken, J. A.; Leidinger, M. R.; OforiAmanfo, G. K.; Brown, H. C.; Businga, T. R.; Stoltz, D. A.; Reznikov, L. R. \& Flaherty, H. A. Glycogen depletion can increase the specificity of mucin detection in airway tissues. BMC Res. Notes, 11:763, 2018.

Mirone, M.; Giannetta, E. \& Isidori, A. M. Selenium and reproductive function. A systematic review. J. Endocrinol. Invest., 36(10 Suppl.):28-36, 2013.

Murray, B. \& Rosenbloom, C. Fundamentals of glycogen metabolism for coaches and athletes. Nutr. Rev., 76(4):243-259, 2018.

Papackova, Z.; Heczkova, M.; Dankova, H.; Sticova, E.; Lodererova, A.; Bartonova, L.; Poruba, M. \& Cahova, M. Silymarin prevents acetaminophen-induced hepatotoxicity in mice. PLoS One, 13(1):e0191353, 2018.

Pettie, J. M.; Caparrotta, T. M.; Hunter, R. W.; Morrison, E. E.; Wood, D. M.; Dargan, P. I.; Thanacoody, R. H.; Thomas, S. H. L.; Elamin, M. E. M. O.; Francis, B.; et al. Safety and efficacy of the SNAP 12-hour acetylcysteine regimen for the treatment of paracetamol overdose. E Clin. Med., 11:11-7, 2019.

Qazi, I. H.; Angel, C.; Yang, H.; Zoidis, E.; Pan, B.; Wu, Z.; Ming, Z.; Zeng, C. J.; Meng, Q.; Han, H.; et al. Role of selenium and selenoproteins in male reproductive function: a review of past and present evidences. Antioxidants (Basel), 8(8):268, 2019.

Ramachandran, A \& Jaeschke, G. Mechanisms of acetaminophen hepatotoxicity and their translation to the human pathophysiology. J. Clin. Transl. Res., 3(1):157-69, 2017.

Rashid, U.; Khan, M. R. \& Sajid, M. Hepatoprotective potential of Fagonia olivieri DC. against acetaminophen induced toxicity in rat. BMC Complement. Altern. Med., 16(1):449, 2016.

Reagan-Shaw, S.; Nihal, M. \& Ahmad, N. Dose translation from animal to human studies revisited. FASEB J., 22(3):659-61, 2008.

Reshma, P. L.; Binu, P.; Anupama, N.; Vineetha, R. C.; Abhilash, S.; Nair, R. H. \& Raghu, K. G. Pretreatment of Tribulus terrestris L. causes anti-ischemic cardioprotection through MAPK mediated anti-apoptotic pathway in rat. Biomed. Pharmacother., 111:1342$52,2019$.

Saiyed, A.; Jahan, N.; Makbul, S. A. A.; Ansari, M.; Bano, H. \& Habib, S. H. Effect of combination of Withania somnifera Dunal and Tribulus terrestris Linn on letrozole induced polycystic ovarian syndrome in rats. Integr. Med. Res., 5(4):293-300, 2016.

Sener, G.; Omurtag, G. Z.; Sehirli, O.; Tozan, A; Yüksel, M.; Ercan, F. \& Gedik, N. Protective effects of Ginkgo biloba against acetaminophen-induced toxicity in mice. Mol. Cell. Biochem., 283:39-45, 2006.

Sener, G.; Sehirli, O.; Cetinel, S.; Yegen, B. G.; Gedik, N. \& AyanogluDulger, G. Protective effects of MESNA (2-mercaptoethane sulfonate) against acetaminophen-induced hepatorenal oxidative damage in mice. J. Appl. Toxicol., 25(1):20-9, 2005. 
AL-DOAISS, A. A. Hepatotoxicity-induced by the therapeutic dose of acetaminophen and the ameliorative effect of oral co-administration of selenium/ Tribulus terrestris extract in rats. Int. J. Morphol., 38(5):1449-1459, 2020

Taju, G.; Jayanthi, M. R. \& Abdul Majeed, S. Evaluation of hepatoprotective and antioxidant activity of Psidium guajava leaf extract against acetaminophen induced liver injury in rats. Int. $J$. Toxicol. Appl. Pharmacol., 1(2):13-20, 2011.

Van Miert, A. S. J. P. A. M. The Use in Animals of Drugs Licensed for Human Use Only. In: Van Miert, A. S. J. P. A. M.; Bogaert, M. G. \& Debackere, M. (Eds.). Comparative Veterinary Pharmacology. Boston, MTP Press, 1986. pp.489-500.

Verma, P. K.; Raina, R.; Sultana, M.; Singh, M. \& Kumar, P. Acetaminophen induced oxidative and histopathological alterations in hepatic tissue: protective effects of Alstonia scholaris leaf extracts. Pharmacogn. J., 8(4):385-91, 2016.

Wang, L.; Wei, W.; Xiao, Q.; Yang, H. \& Ci, X. Farrerol ameliorates APAP-induced hepatotoxicity via activation of Nrf2 and autophagy. Int. J. Biol. Sci., 15(4):788-99, 2019.

Wolf, A.; Diez-Fernandez, C.; Trendelenburg, C. F.; Prieto, P.; Hary, S. \& Trammer, W. E. Paracetamol induced oxidative stress in rat hepatocytes. J. Pharm. Exp. Ther, 280:1328-34, 1997.

Yemitan, O. K. \& Izegbu, M. C. Protective effects of Zingiber officinale (Zingiberaceae) against carbon tetrachloride and acetaminophen-induced hepatotoxicity in rats. Phytother. Res., 20(11):997-1002, 2006.

Yoon, E.; Babar, A.; Choudhary, M.; Kutner, M. \& Pyrsopoulos, N. Acetaminophen-induced hepatotoxicity: a comprehensive update. J. Clin. Transl. Hepatol., 4(2):131-42, 2016.

Zhou, H. C.; Wang, H.; Shi, K.; Li, J.; Zong, Y. \& Du, R. Hepatoprotective effect of Baicalein against acetaminophenInduced acute liver injury in mice. Molecules, 24(1):131, 2019.
Corresponding author:

Amin A. Al-Doaiss

Department of Biology

College of Science King Khalid University

P.O. Box: 9004 Abha

Postal Code 61413

SAUDI ARABIA

Email: aaldoaiss@kku.edu.sa

Received: 27-02-2020

Accepted: 02-05-2020 